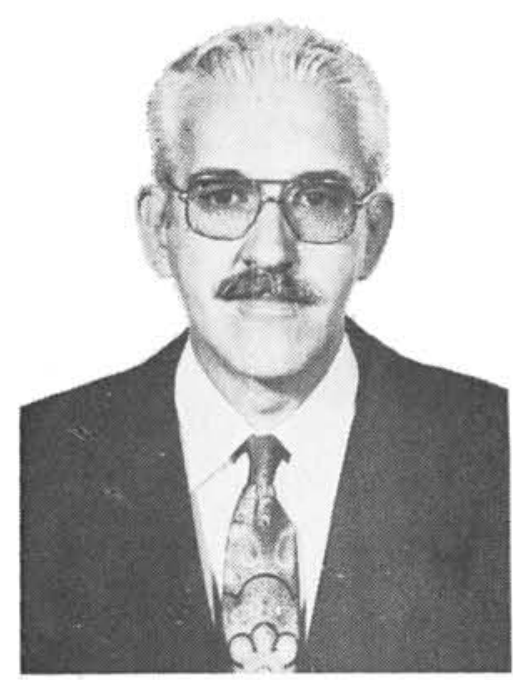

\title{
NABOR RICARDO RÜEGG \\ 12-07-1931 - 24-01-1982
}

Na manhã do dia 25 de janeiro de 1982 a comunidade geológica foi surpreendida com a notícia do falecimento do Professor Doutor Nabor Ricardo Rüegg em condiçбes trágicas, desaparecendo, assim, prematuramente, o professor e o geólogo que pertenceu à turma de Geologia de 1959.

Já como estudante demonstrou ser pessoa de interesses múltiplos nos campos de arte, filosofia, literatura, pedagogia e geologia.

A vida profissional foi dedicada inteiramente ao ambiente universitário, no Departamento de Mineralogia e Petrologia da Universidade de São Paulo e, durante certo tempo, na Universidade Estadual Paulista (UNESP) em Rio Claro e São José do Rio Preto.

Doutorou-se em 1969, prestou concurso para Professor Livre-Docente em 1975 e em 1979 foi aprovado em concurso para Professor Adjunto. Realizou estágios de longa duração na Universidade da Califórnia, Berkeley e na Universidade de Paris-Sud, além de estágios de curta duração nas Universidades de Coimbra, Indiana e Norwestern University.

Professor por vocação, sempre esteve profundamente interessado na problemática da metodologia do ensino de Ciências e, em especial, de Geologia, não só para o Curso Secundário como também Superior. Nesta área sua contribuição maior foi a tradução e adaptação da série "Investigando a Te ra".

Com satisfação foi responsável, durante anos, pelas disciplinas introdutórias de Mineralogia e Petrologia para os estudantes dos Cursos de Geologia, Química, Biologia e Geografia.

De personalidade cativante e estimulante, orientou numerosos bolsistas, estagiários e pós-graduados, interessando-os nos problemas que o apaixonavam.

No campo da Petrologia merece maior destaque sua contribuição ao conhecimento da petrologia e geoquímica das rochas basálticas, em especial do Sul do Brasil, com várias publicaçбes no Brasil e Exterior.

Os dotes artísticos referentes à arte gráfica foram usados no planejamento, organização e editoraçấ) do Boletim do Instituto de Geociências.

Nos últimos anos prestou colaboração junto ao Departamento de Geociências do Instituto de Biociências, Letras e Ciências Exatas - UNESP - São José do Rio Preto e, em 1979, foi designado Vice-Diretor deste Instituto. Nesta função - administrador - revelou, com brilhantismo, mais uma faceta de suas múltiplas qualidades.

O Instituto de Geociências da Universidade de São Paulo, através dos seus docentes, alunos : funcionários, presta homenagem ao Professor Doutor Nabor Ricardo Rüegg pelo muito que fez e deixou na instituição onde viveu e dedicou a sua vida profissional. 